\title{
Socioeconomic inequalities related to dental care needs among adolescents and adults living in the state of Minas Gerais, Brazil
}

\section{Desigualdades socioeconômicas relacionadas à necessidade de tratamento odontológico entre adolescentes e adultos residentes em Minas Gerais, Brasil}

\author{
Fabíola Bof de Andrade ${ }^{1}$ (D), Flávia Cristina Drumond Andrade 2 (D) \\ 'Instituto René Rachou, Fundação Oswaldo Cruz (FIOCRUZ) - Belo Horizonte (MG), Brasil. \\ ${ }^{2} S$ chool of Social Work, University of Illinois - Urbana (IL), United States.
}

How to cite: Andrade FB, Andrade FCD. Socioeconomic inequalities related to dental care needs among adolescents and adults living in the state of Minas Gerais, Brazil. Cad Saúde Colet, 2021;29(3):322-329. https://doi.org/10.1590/1414$462 \times 202129030186$

\begin{abstract}
Background: There is significant evidence of inequalities in the need for dental treatment, and their monitoring is essential for public health planning. Objective: To measure the extent of the association between socioeconomic inequality and need for dental care. Method:This study used data from the 2011 Survey of Oral Health Conditions, including a representative sample of adolescents $(n=2,310)$ and adults $(n=1,188)$ from the state of Minas Gerais, Brazil. Need for dental treatment was evaluated according to criteria of the World Health Organization (WHO). Family income was used as a measure of socioeconomic status. The magnitude of socioeconomic inequalities related to the need for treatment was assessed using the slope index of inequality (SII) and the relative index of inequality (RII). Results: Among adolescents, the SII was $-22.9 \%(95 \% \mathrm{Cl}-34.8 ;-11.0)$ and the estimated RII was 0.61 (95\% Cl 0.47; 0.79). Among adults, the SII was $-28.0 \%(95 \% \mathrm{Cl}-39.8 ;-16.3)$ and the RII was $0.58(95 \% \mathrm{Cl} 0.45 ; 0.74)$. Conclusion: There are socioeconomic inequalities regarding the need for dental treatment, and individuals with lower family income present a higher prevalence of need.
\end{abstract}

Keywords: oral health; socioeconomic factors; Brazil; dental care.

\section{Resumo}

Introdução: As desigualdades na necessidade de tratamento odontológico têm sido consistentemente relatadas, sendo o monitoramento delas essencial para o planejamento da saúde pública. Objetivo: Avaliar a magnitude da desigualdade socioeconômica relacionada à necessidade de atendimento odontológico. Método: Utilizaram-se dados da Última Pesquisa de Condições de Saúde Bucal de Minas Gerais, realizada em 2011, com amostra representativa de adolescentes $(n=2.310)$ e adultos $(n=1.188)$. A necessidade de tratamento odontológico foi avaliada de acordo com os critérios da Organização Mundial de Saúde (OMS). A renda familiar foi utilizada como medida de posição socioeconômica. A magnitude das desigualdades socioeconômicas relacionadas à necessidade de tratamento foi avaliada por meio do Índice Absoluto de Desigualdades (IAD) e Índice Relativo de Desigualdades (IRD). Resultados: Entre adolescentes, o IAD foi de -22,9\% (IC95\% -34,8; -11,0) e o IRD estimado em 0,61 (IC95\% 0,47; 0,79). Entre adultos, o IAD foi de -28,0\% (IC95\% -39,8; -16,3) e IRD 0,58 (IC 95\% 0,45; 0,74). Conclusão: Existem desigualdades socioeconômicas relacionadas à necessidade de tratamento odontológico, sendo que indivíduos com menor renda familiar apresentam maior prevalência de necessidades.

Palavras-chave: saúde bucal; fatores socioeconômicos; Brasil; assistência odontológica.

Study carried out in the State of Minas Gerais - Brasil.

Correspondence: Fabíola Bof de Andrade. E-mail: fabiola.bof@fiocruz.br

Conflict of interests: nothing to declare.

Received on: May 10, 2019. Accepted on: Aug. 10, 2020
This is an Open Access article distributed under the terms of the Creative Commons Attribution License, which permits unrestricted use, distribution, and reproduction in any medium, provided the original work is properly cited. 


\section{INTRODUCTION}

Oral health problems, such as dental caries in permanent teeth, are among the most prevalent diseases in the world ${ }^{1}$. Dental caries are preventable, and they affect about $35 \%$ of the population worldwide'. Given the cumulative nature of oral health problems, assessment of the need for dental treatment throughout life is essential for disease prevention and restorative treatment. Also, unmet dental care need is a proxy for the absence or failure of health services, and reflects people's difficulty in obtaining adequate and affordable services more generally ${ }^{2}$.

In Brazil, data from the latest National Oral Health Survey show that one quarter of adolescents aged 15-19 years had had a toothache in the six months before the interview ${ }^{3}$. Among adults aged $35-44$ years, $75 \%$ needed dental treatment ${ }^{3}$. The Brazilian public health system provides dental treatment to all residents free of charge, and access has increased over the past decade ${ }^{4}$, but socioeconomic inequities in dental health and the need for treatment remain ${ }^{2}$. Roncalli et al. ${ }^{2}$ observed that adults with lower educational levels had a higher prevalence of need for restorative treatment, extractions, and prostheses than those with higher education levels.

Socioeconomic inequalities in oral health are well documented in high-income countries 5 . Monitoring socioeconomic inequalities is essential to assess changes in health conditions and evaluate the unmet needs of socially vulnerable groups ${ }^{6}$. The United Nations (UN) 2030 Agenda for Sustainable Development promotes the need to investigate inequalities, but few studies have addressed socioeconomic inequalities related to the need for dental treatment ${ }^{2,7}$. The use of complex, regression-based measures to quantify these inequalities is particularly scarce in Brazil ${ }^{8-10}$. Such measures enable the assessment of health status across all ranges of socioeconomic status ${ }^{11}$ and of the magnitude of the inequalities between groups and over time $^{12}$. The paucity of evidence is among the main barriers to reduce global inequities in oral health ${ }^{13}$. This study measured the extent of association between socioeconomic inequality and need for dental care in a representative sample of adolescents and adults from the State of Minas Gerais, Brazil.

\section{METHOD}

The data used were based on a cross-sectional study from the 2011 Survey of Oral Health Conditions of the population of the State of Minas Gerais (SB Minas), Brazil ${ }^{14}$. The State of Minas Gerais is located in the southeastern region and is the second most populous state in the country, with about 20 million inhabitants according to the Brazilian Institute of Geography and Statistics (IBGE) ${ }^{15}$.

The SB Minas survey is a population-based sample representative of the State of Minas Gerais and two domains of nonmetropolitan areas. These domains were defined according to the allocation factor, and an indicator built based on the Health Needs Index and the Economic Size Index. The allocation factor defined nonmetropolitan cities in Minas Gerais in quartiles according to financial resources: Group 1 cities have the most financial resources, and Group 4 cities have the highest need. These groups were subdivided into two domains: Domain 1 included Groups 1 and 2, and Domain 2 included Groups 3 and 4. The sampling process consisted of two stages in the capital (the first using the census tract and the second using the household) and three stages in the cities located out of the metropolitan region (using municipality, census tract, and household $)^{16}$.

Each fieldwork team consisted of a dentist and a trained note taker who visited the participants' domiciles to perform examinations and administer interviews. The questionnaire addressed socioeconomic conditions, the use of dental services, and self-reported oral health. The dentists were trained to give clinical oral health exams according to the methodology internationally standardized by the World Health Organization $(\mathrm{WHO})^{17}$. The minimum kappa considered acceptable was $0.65^{18}$. The entire description of the study and sampling process are published elsewhere ${ }^{14}$. The SB Minas was designed to be representative of the age distribution of the State population. It conforms with the WHO suggestion to include five age groups: $5,12,15-19,35-44$ and $65-74$ years $^{17}$. The present study used data from adolescents aged 
12 and $15-19$ years $(n=2,310)$ and adults aged $35-44$ years $(n=1,188)$ who voluntarily participated in the study and had complete information for all study variables. From the original SB Minas sample, 109 cases were excluded from the adolescent group and 19 from the adult group due to missing values in one or more of the variables used in the study.

WHO gives several reasons for research to target 12-year-olds and people aged 15-19. In the former, all permanent teeth, except third molars, will be erupted, and in many countries, it is the last age that a reliable sample can be obtained through the school system. Targeting the latter enables evaluation of periodontal disease in late adolescence ${ }^{17}$. Both groups are representative of adolescence; therefore, given our study aim, the groups were considered together.

Need for dental treatment was the dependent variable, which was evaluated according to WHO criteria ${ }^{17}$. Each tooth was classified according to the following treatment needs: 1 ) no need, 2) restoration of one surface, 3) restoration of two or more surfaces, 4) crown for any reason, 5) aesthetic facet, 6) pulp treatment and restoration, 7) extraction, 8) remineralization of white spot, and 9) sealant. The final variable was classified as yes or no. Individuals in need of at least one dental treatment from the aforementioned list were considered as in need for dental treatment, in line with a previous study ${ }^{19}$.

Family monthly income was the covariate used as a measure of socioeconomic status in this study. The variable was collected during the survey using the same seven income levels used in the Brazilian National Oral Health Survey, as follows: $\leq 250$ BRL, 251-500 BRL, 501-1,500 BRL, 1,501-2,500 BRL, 2,501-4,500 BRL, 4,501-9,500 BRL, and > 9,500 BRL. One BRL corresponded to 0.586 USD at the time this study was conducted. In this study, this variable was recategorized as $\leq 500 \mathrm{BRL}, 501-1,500 \mathrm{BRL}, 1,501-2,500 \mathrm{BRL}, 2,501-4,500 \mathrm{BRL}$, and >4,501 BRL ${ }^{20}$. For adolescents, this information was given by the head of the household.

Descriptive analysis of the sample was carried out, followed by bivariate analysis using the Rao-Scott chi-squared test to examine the association between the outcome (need for dental treatment) and the covariates (family income and sex). Following a previous study ${ }^{21}$, the magnitude of socioeconomic inequalities related to the need for dental treatment was assessed using the SII and RII . Both measures were obtained by regressing the outcome variable on the socioeconomic status (family income) measure. Family monthly income was included in the model in the form of a cumulative position score where the lowest family income corresponded to 0 and the highest income to 1 . The calculation involved ordering the sample from the family with the lowest income to the family with the highest income. Each income category was assigned a value that corresponds to the midpoint of the cumulative distribution of the measure ${ }^{11}$. The SII represents the absolute difference in the prevalence of treatment need among those with higher and lower socioeconomic status, whereas the RII is the relative difference between the groups. A negative SII and an RIl of less than 1 indicate that individuals at higher income levels have a lower prevalence of dental treatment need. All analyses were performed using the Poisson regression as previously applied ${ }^{21}$ and adjusted for the participant's sex. The models were separated according to the age groups of adolescents (12 and 15-19 years) and adults (35-44 years). For all analyses, a 95\% confidence interval (95\% Cl) was estimated. Analyses were performed using the Stata S.E. 15.0 software, using sample weights and the survey (svy) command to account for the complex survey design.

The Research Ethics Committee of the Pontifical Catholic University of Minas Gerais approved the research protocol of the SB Minas study. All participants signed an informed consent form (ICF) prior to study commencement.

\section{RESULTS}

The mean age of the participating adolescents was 15.8 years (95\% Cl 15.7;15.9); $21.3 \%$ were 12-year-old and $78.7 \%$ were 15-19-year-old. Among the adults, the mean age was 39.4 years $(95 \% \mathrm{Cl} 39.2 ; 39.6)$. Table 1 shows the distribution of age groups according to sex and family income. In both groups, most participants were female and reported a monthly income of 501-1,500 BRL. 
According to the bivariate analysis, the need for dental treatment was significantly associated with family income among adolescents and adults (Table 2). The Equiplot chart (http://www.equidade.org/equiplot.php) was used to demonstrate the relationship between income categories in each age group and the prevalence of need for dental treatment. Figure 1 shows that the prevalence of need was higher among those with lower incomes.

Analysis of the magnitude of inequalities regarding need for dental treatment is presented in Table 3. There were significant absolute and relative inequalities among adolescents and adults. In the group of adolescents, the SII was -22.9 percent points, and the RII was 0.61 . Among the adults, the SII was -28.0 percent points and the RII was 0.58 . These results demonstrate that, for both groups, individuals in the lower income position had a higher prevalence of need for dental treatment (Table 3).

Table 1. Descriptive statistics of independent variables for adolescents and adults, SB Minas Gerais - 2011

\begin{tabular}{|c|c|c|}
\hline & Adolescents $(n=2,310)$ & $\begin{array}{c}\text { Adults } \\
(\mathrm{n}=1,188)\end{array}$ \\
\hline & $\%(95 \% \mathrm{Cl}) *$ & $\%(95 \% \mathrm{Cl}) *$ \\
\hline \multicolumn{3}{|l|}{ Sex } \\
\hline Male & $46.8(43.6-49.9)$ & $35.0(31.5-38.7)$ \\
\hline Female & $53.2(50.1-56.4)$ & $65.0(61.3-68.5)$ \\
\hline \multicolumn{3}{|c|}{ Family Income (BRL) } \\
\hline$\leq 500$ & $9.2(7.2-11.7)$ & $6.3(4.7-8.3)$ \\
\hline $501-1,500$ & $49.8(45.4-54.2)$ & $48.4(42.5-54.3)$ \\
\hline $1,501-2,500$ & $27.5(23.3-32.1)$ & $27.5(23.4-32.0)$ \\
\hline $2,501-4,500$ & $10.8(8.3-14.1)$ & $13.2(10.4-16.7)$ \\
\hline$>4,501$ & $2.7(1.5-4.8)$ & $4.7(3.0-7.3)$ \\
\hline
\end{tabular}

*95\% Cl: $95 \%$ confidence interval

Table 2 - Proportion of adolescents and adults with dental care treatment needs by sex and family income, SB Minas Gerais - 2011

\begin{tabular}{|c|c|c|c|c|}
\hline & \multicolumn{2}{|c|}{ Adolescents $(n=2,310)$} & \multicolumn{2}{|c|}{ Adults $(n=1,188)$} \\
\hline & $\%(95 \% \mathrm{Cl})$ & $p$-value & $\%(95 \% \mathrm{Cl})$ & $p$-value \\
\hline Sex & & 0.888 & & 0.991 \\
\hline Male & $45.8(41.3,50.4)$ & & $51.2(44.7,57.7)$ & \\
\hline Female & $46.2(41.8,50.6)$ & & $51.3(46.0,56.5)$ & \\
\hline Family Income (BRL) & & $<0.001$ & & $<0.001$ \\
\hline$\leq 500$ & $65.0(55.4,73.5)$ & & $71.0(58.9,80.7)$ & \\
\hline $501-1,500$ & $47.1(41.8,52.4)$ & & $55.9(50.1,61.6)$ & \\
\hline $1,501-2,500$ & $45.3(39.4,51.3)$ & & $47.2(40.8,53.8)$ & \\
\hline $2,501-4,500$ & $37.0(29.2,45.5)$ & & $40.6(30.9,51.2)$ & \\
\hline$>4,501$ & $4.8(1.7,12.9)$ & & $30.0(18.1,45.4)$ & \\
\hline
\end{tabular}

Note: Chi-squared tests used in the analyses 


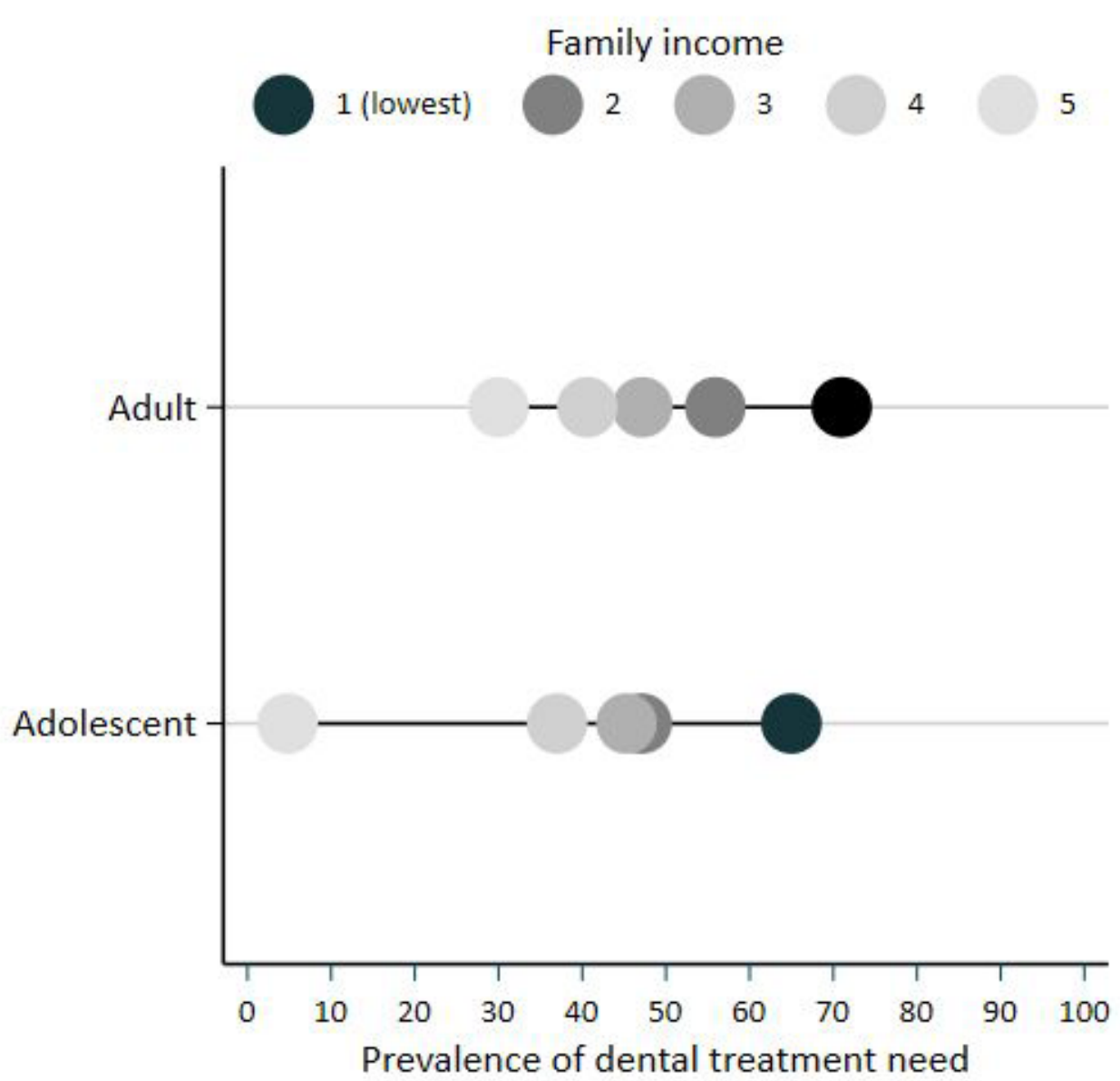

Figure 1. Prevalence of dental treatment need according to family income and age group

Table 3. Absolute inequality (SII) and relative inequality (RII) indexes regarding the need for dental treatment among adolescents and adults. SB Minas Gerais - 2011

\begin{tabular}{ccc} 
& SII $(\mathbf{9 5 \%}$ CI) & RII $(\mathbf{9 5} \% \mathbf{C I})$ \\
\hline Adolescents & $-22.9(-34.8 ;-11.0)$ & $0.61(0.47 ; 0.79)$ \\
\hline Adults & $-28.0(-39.8 ;-16.3)$ & $0.58(0.45 ; 0.74)$ \\
\hline
\end{tabular}

\section{DISCUSSION}

This study evaluated the existence of socioeconomic inequalities related to the need for dental treatment among adolescents and adults living in the State of Minas Gerais, Brazil. The results showed that socioeconomic inequalities regarding the need for dental treatment are significant, thereby indicating a higher concentration of need among individuals with the lowest family incomes.

Prevalence of the need for dental treatment was high in both age groups, reaching about half of the adults (51\%) and nearly half of the adolescents (46\%). The existence of few similar studies in Brazil makes it difficult to compare the results. However, the prevalence for adults was close to that observed in the Brazilian population, where $58 \%$ of adults had one or more teeth in 
need of restorative treatment ${ }^{2}$. Prevalence of the need for dental treatment in Minas Gerais and in Brazil in general is much higher than in developed countries ${ }^{22}$. Malecki et al. ${ }^{22}$ reported that $16 \%$ of adults residing in the US state of Wisconsin needed dental treatment. In the Australian population, the need for treatment of caries alone was $25.8 \%$ among 15 to 34 -year-olds.

Analysis of the inequalities confirmed previous findings that suggested a significant association between socioeconomic factors and need for dental treatment ${ }^{2,7}$, in which individuals with lower socioeconomic levels presented a greater need for dental treatment. Roncalli et al. ${ }^{2}$ demonstrated that individuals' socioeconomic conditions were the main factor associated with inequalities in their need for dental treatment in Brazil. Those authors found that $70 \%$ of the individuals at the lowest income level needed treatment, compared with $38 \%$ of those at the highest income level'.

The present study analyzed the magnitude of income-related inequalities among individuals in need for dental treatment. To this end, two complex measures of inequalities were used. These absolute and relative measures enable quantification of the magnitude of differences between socioeconomic levels using the entire population distribution ${ }^{12}$. Also, they facilitate the monitoring of inequalities over time ${ }^{12}$. Analysis of the absolute inequalities showed significant gaps between the low- and high-income groups, 22.9 and 30 percentage points for adults and adolescents, respectively. Inequalities were also significant from the relative point of view, with the relative differences between the highest- and lowest-income levels of approximately 0.60 for both age groups. These results reinforce the importance of individual socioeconomic conditions found in previous study conducted with the Brazilian population².

Although this study does not allow inference about the causal mechanisms related to need for dental treatment, differences concerning family income suggest that the ability to pay for services is important in this context. According to the last National Health Survey, public services accounted for only $19.6 \%$ of the dental care ${ }^{23}$. However, the use of public services is higher among individuals with lower socioeconomic status ${ }^{24,25}$. A previous study ${ }^{26}$ found that users of public health programs presented a higher unmet need for treatment than those with private health insurance. Although access to dental services has improved in the Brazilian public health system over the past decade ${ }^{4}$, the inequities found suggest that barriers to access persist, and that the public services themselves have limitations. Some researchers have suggested that inequalities related to disease prevalence are lower than those related to the treatment of oral diseases ${ }^{7}$. In other words, worse socioeconomic conditions do not translate to greater disease experience, but rather influence the use and nature of treatment services ${ }^{7}$.

The use of need for treatment as a measure of access to oral health services is one of the strengths of this study. Other studies have used recent or frequent use of dental services as access measures ${ }^{27-29}$, but these measures fail to assess the quality and completeness of the service provided. Another strength of the present study is the use of a large representative sample in each target age group proposed by $\mathrm{WHO}$, allowing comparison of the results with future research. A limitation to the cross-sectional study is that it does not allow exploration of the causal mechanisms underlying its findings. In addition, data are limited to one Brazilian state, which restricts the study generalizability. Another limitation is the use of a composite measure of treatment need that combines needs involving different levels of dental disease severity. Future studies would benefit from including information on severity. The results were not adjusted for other general health conditions that may affect the need for dental services, as they were not available in the survey. As parental education was not addressed in the SB Minas, inequalities could not be adjusted for or estimated using this socioeconomic measure, which may have influenced the magnitude of the inequalities found among adolescents. Finally, the use of a different socioeconomic status suggests different magnitudes of inequalities, as each measure captures different socioeconomic aspects, although they are complementary and may overlap ${ }^{30}$.

The high prevalence of dental treatment needs across the study sample, especially among those with low income, shows that there is a difference between the needs and the treatment offered to or accessed by the population in the state of Minas Gerais, Brazil. Thus, these findings draw attention to the need for improving access to and quality of treatment among different 
socioeconomic groups so that the population demands can be met. Moreover, as previously proposed ${ }^{31}$, the findings point to the need for action to ensure that policymakers recognize oral health as a priority, such that they integrate it into the public health agenda to achieve universal health coverage.

\section{REFERENCES}

1. Marcenes W, Kassebaum NJ, Bernabé E, Flaxman A, Naghavi M, Lopez A, et al. Global burden of oral conditions in 1990-2010: a systematic analysis.. J Dent Res. 2013;92(7):592-7. http://dx.doi. org/10.1177/0022034513490168. PMid:23720570.

2. Roncalli AG, Tsakos G, Sheiham A, Souza GC, Watt RG. Social determinants of dental treatment needs in Brazilian adults. BMC Public Health. 2014;14(1):1097. http://dx.doi.org/10.1186/1471-2458-14-1097. PMid:25339315.

3. Brasil. 2010: pesquisa Nacional de Saúde Bucal: resultados principais. 1. ed. Brasília: Ministério da Saúde, Secretaria de Atenção à Saúde, Secretaria de Vigilância em Saúde; 2014. 116 p.

4. Pucca GA Jr, Gabriel M, Araujo ME, Almeida FCS. Ten years of a national oral health policy in Brazil: innovation, boldness, and numerous challenges. J Dent Res. 2015;94(10):1333-7. PMid:26316461.

5. Watt RG, Listl S, Peres M, Heilmann A. Social inequalities in oral health: from evidence to action. London: $\mathrm{UCL} ; 2015$.

6. Hosseinpoor AR, Bergen N. National health inequality monitoring: a step-by-step manual. Geneva:WHO; 2017. $44 \mathrm{p}$.

7. Mejia G, Jamieson LM, Ha D, Spencer AJ. Greater inequalities in dental treatment than in disease experience. J Dent Res. 2014;93(10):966-71. http://dx.doi.org/10.1177/0022034514545516. PMid:25081039.

8. Andrade FB, Antunes JLF, Lima-Costa MF, Oliveira C. Life course socioeconomic inequalities and oral health status in later life: ELSI-Brazil. Rev Saude Publica. 2019;52(Suppl. 2):7s. http://dx.doi.org/10.11606/ s1518-8787.2018052000628.

9. Andrade FB, Antunes JLF. Trends in socioeconomic inequalities in the prevalence of functional dentition among older people in Brazil. Cad Saude Publica. 2018;34(10):e00202017. http://dx.doi.org/10.1590/0102311x00202017. PMid:30329004.

10. Peres MA, Luzzi L, Peres KG, Sabbah W, Antunes JL, Do LG. Income-related inequalities in inadequate dentition over time in Australia, Brazil and USA adults. Community Dent Oral Epidemiol. 2015;43(3):21725. http://dx.doi.org/10.1111/cdoe.12144. PMid:25611323.

11. World Health Organization. Handbook on health inequality monitoring: with a special focus on low-and middle-income countries. Geneva: WHO; 2013. 105 p.

12. Harper S, Lynch J. Methods for measuring cancer disparities: using data relevant to healthy people 2010 cancer-related objectives. Bethesda: National Cancer Institute; 2010. http://doi.apa.org/get-pe-doi. cfm?doi=10.1037/e606392012-001.

13. Williams DM. The research agenda on oral health inequalities: the IADR-GOHIRA initiative. Med Princ Pract. 2014;23(Suppl. 1):52-9. http://dx.doi.org/10.1159/000356934. PMid:24401749.

14. Minas Gerais. Pesquisa das condições de saúde bucal da população mineira: resultados principais [Internet]. Belo Horizonte: Secretaria de Estado de Saúde, Subsecretaria de Políticas e Ações de Saúde, Superintendência de Redes de Atenção à Saúde, Diretoria de Saúde Bucal; 2013 [cited 2019 May 10]. Available from: http://www.saude.mg.gov.br/images/documentos/SBMinas_Relatorio_Final.pdf

15. Instituto Brasileiro de Geografia e Estatística [Internet]. Rio de Janeiro: IBGE; 2019 [cited 2019 May 10]. Available from: https://ww2.ibge.gov.br/home/estatistica/populacao/estimativa2012/estimativa_tcu. shtm

16. Nascimento AR, Andrade FB, César CC. Factors associated with agreement between self-perception and clinical evaluation of dental treatment needs in adults in Brazil and Minas Gerais. Cad Saude Publica. 2016;32(10):e00039115. PMid:27828608.

17. World Health Organization. Oral health surveys: basic methods [Internet]. 4th ed. Geneva: WHO; 1997 [cited 2019 May 10]. Available from: http://apps.who.int/iris/bitstream/handle/10665/41905/9241544937. pdf? sequence $=1$ \&isAllowed $=y$

18. Pinto RS, Leal DL, Santos JS, Roncalli AG, Projeto SB. Minas Gerais 2012: pesquisa das condições de saúde bucal da população mineira: métodos e resultados principais. Arq Odontol. 2018;54:e14. 
19. Novaes LCM, Alves $\mathrm{P}$ Fo, Novaes TA, Corvino MPF. Fatores associados à necessidade de tratamento odontológico: estudo transversal na Universidade Federal Fluminense, Rio de Janeiro, 2013. Epidemiol Serv Saude. 2018;27(4):e2018102. http://dx.doi.org/10.5123/S1679-49742018000400017. PMid:30570034.

20. Vieira JMR, Rebelo MAB, Martins NMO, Gomes JFF, Vettore MV. Contextual and individual determinants of non-utilization of dental services among Brazilian adults. J Public Health Dent. 2019;79(1):60-70. http:// dx.doi.org/10.1111/jphd.12295. PMid:30468261.

21. Wagstaff A, Paci P, van Doorslaer E. On the measurement of inequalities in health. Soc Sci Med. 1991;33(5):545-57. http://dx.doi.org/10.1016/0277-9536(91)90212-U. PMid:1962226.

22. Malecki K, Wisk LE, Walsh M, McWilliams C, Eggers S, Olson M. Oral health equity and unmet dental care needs in a population-based sample: findings from the survey of the health of Wisconsin. Am J Public Health. 2015;105(Suppl. 3):S466-74. http://dx.doi.org/10.2105/AJPH.2014.302338. PMid:25905843.

23. Instituto Brasileiro de Geografia e Estatística. Pesquisa nacional de saúde: 2013: acesso e utilização dos serviços de saúde, acidentes e violências: Brasil, grandes regiões e unidades da federação. Rio de Janeiro: IBGE; 2015.

24. Andrade FB, Andrade FCD, Noronha K. Measuring socioeconomic inequalities in the use of dental care services among older adults in Brazil. Community Dent Oral Epidemiol. 2017;45(6):559-66. http://dx.doi. org/10.1111/cdoe.12323. PMid:28745803.

25. Peres KG, Peres MA, Boing AF, Bertoldi AD, Bastos JL, Barros AJD. Redução das desigualdades sociais na utilização de serviços odontológicos no Brasil entre 1998 e 2008. Rev Saude Publica. 2012;46(2):250-8. http://dx.doi.org/10.1590/S0034-89102012000200007.

26. Ramraj C, Azarpazhooh A, Dempster L, Ravaghi V, Quiñonez C. Dental treatment needs in the Canadian population: analysis of a nationwide cross-sectional survey. BMC Oral Health. 2012;12(1):46. http://dx.doi. org/10.1186/1472-6831-12-46. PMid:23102263.

27. Ferreira CO, Antunes JLF, Andrade FB. Andrade FB de. Fatores associados à utilização dos serviços odontológicos por idosos brasileiros. Rev Saude Publica. 2013;47(Suppl. 3):90-7. http://dx.doi.org/10.1590/ S0034-8910.2013047004721.

28. Reda SM, Krois J, Reda SF, Thomson WM, Schwendicke F. The impact of demographic, health-related and social factors on dental services utilization: systematic review and meta-analysis. J Dent. 2018;75:1-6. http://dx.doi.org/10.1016/j.jdent.2018.04.010. PMid:29673686.

29. Gibilini C, Esmeriz CE C, Volpato LF, Meneghim ZMAP, Silva DD, Sousa MLR. Acesso a serviços odontológicos e auto-percepção da saúde bucal em adolescentes, adultos e idosos. Arq Odontol. 2010;46(4):213-23.

30. Howe LD, Galobardes B, Matijasevich A, Gordon D, Johnston D, Onwujekwe O, et al. Measuring socioeconomic position for epidemiological studies in low- and middle-income countries: a methods of measurement in epidemiology paper. Int J Epidemiol. 2012;41(3):871-86. http://dx.doi.org/10.1093/ije/ dys037. PMid:22438428.

31. Mathur MR, Williams DM, Reddy KS, Watt RG. Universal health coverage: a unique policy opportunity for oral health. J Dent Res. 2015;94(3 Suppl.):3S-5S. http://dx.doi.org/10.1177/0022034514565648. PMid:25710897. 